\title{
KONFLIK DAN POTENSI KONFLIK DALAM PENGELOLAAN SUMBERDAYA KERANG HIJAU DI KALIBARU JAKARTA UTARA
}

\author{
Nendah Kurniasari ${ }^{1}$, Arif Satria ${ }^{2}$ dan Said Rusli ${ }^{2}$ \\ ${ }^{1}$ Balai Besar Penelitian Sosial Ekonomi Kelautan dan Perikanan \\ Jl. KS. Tubun Petamburan VI Jakarta 10260 \\ Telp. (021) 53650162, Fax. (021)53650159 \\ E-mail: nendah_k04@yahoo.co.id \\ ${ }^{2}$ Dosen Fakultas Ekologi Manusia Pertanian Bogor
}

Diterima 16 Februari 2012 - Disetujui 3 Desember 2012

\begin{abstract}
ABSTRAK
Sebagai entitas usaha yang memanfaatkan sumberdaya pesisir yang bersifat common property resources, pembudidaya dan pengolah kerang hijau harus berhadapan dengan berbagai pelaku yang mempunyai kepentingan yang berbeda terhadap wilayah pesisir yang sama. Kondisi ini memunculkan berbagai potensi konflik terkait dengan pengaturan peruntukan wilayah dan kewenangan dalam pengelolaan sumberdaya pesisir. Penelitian ini berupaya untuk menganalisis eksistensi konflik dan strategi penyelesaian konflik yang terjadi dalam pengelolaan sumberdaya kerang hijau di Kalibaru Jakarta Utara. Metode penelitian yang digunakan adalah metode kualitatif dengan mengambil kasus di Kelurahan Kalibaru, Kecamatan Cilincing Kotamadya Jakarta Utara. Analisa data dilakukan mengacu pada teori struktural fungsional dan teori konflik. Hasil penelitian menunjukkan bahwa sumber potensi konflik berawal dari perbedaan pemaknaan antar pihak yang berkonflik, serta penegakkan aturan yang tidak semestinya. Jenis konflik terdiri dari konflik kewenangan, konflik perebutan wilayah dan konflik ekologi yang terjadi antara pembudidaya dan pengolah kerang hijau dengan nelayan, pemerintah dan pihak industri. Penyelesaian konflik cenderung dapat diselesaikan dengan cepat secara kekeluargaan jika yang berkonflik merupakan pengguna perairan secara langsung yang memahami kesepakatan lokal yang berlaku di wilayah tersebut. Namun demikian konflik ini pun mempunyai dampak positif yaitu menumbuhkan kesadaran pembudidaya dan pengolah kerang hijau untuk berkelompok, mempercepat terjadinya penyelesaian atas isu-isu yang berkembang selama ini, serta membimbing kepada aliansi antar kelompok yang berkepentingan.
\end{abstract}

Kata kunci: konflik, wilayah pesisir, kerang hijau

\section{Abstract: Conflicts and Potential Conflicts in Resource Management of Perna Viridis in Kalibaru, North Jakarta. By: Nendah Kurnisari, Arif Satria and Said Rusli.}

As an Business entity that utilizes coastal resources which are common property resources, fishers and perna viridis farmers have to deal with various actors who have different interested in the same coastal areas. This condition raises many potential conflict associated with the setting of designated territory and authority in managing the coastal resources. This research tried to analyze the existence of the conflict and its solving strategies in the management of Perna viridis in Kalibaru, North Jakarta. This research was using a qualitative research methods in the village Kalibaru, Cilincing district, North Jakarta Municipality. Analysis data were refered to the structural-functional theory and theory of conflict. Results showed that sources of the conflict were originated from the differences in interpreting of the conflicting parties, as well as the enforcing the improper rules. Types of conflict consisted of the conflict of authority, territory and ecology that occur between farmers and Perna viridis processor with fishers, government and industry. The conflict tend, to be resolved quickly, especially those who directly used water resource understanding the existing local agreement. The conflict, however, has had a positive impact on raise awareness among 
farmers and Perna viridis processor to accelerate the completion of growing issues and lead to alliances between interest groups.

Keywords: conflict, coastal area, perna viridis

\section{PENDAHULUAN}

Kerang hijau merupakan komoditi yang banyak diusahakan di wilayah perairan teluk Jakarta. Pada tahun 2009 di Kecamatan Cilincing tercatat sejumlah 1.626 orang yang terlibat dalam usaha pembudidayaan dan pengolahan kerang hijau (Dinas Peternakan, Perikanan dan Kelautan DKI Jakarta, 2010). Salah satu sentra kegiatan tersebut adalah Desa Kalibaru Kecamatan Cilincing. Kondisi ini selain ditunjang oleh kondisi perairan teluk Jakarta yang kaya akan fitoplankton sebagai unsur hara bagi perkembangbiakan kerang hijau juga ditunjang oleh kondisi geografis yang strategis serta pelaksanaan aturan-turan formal yang belum mengikat.

Posisi pesisir Kalibaru yang strategis baik ditinjau dari aspek geografis maupun ekonomi menjadikan banyak masyarakat tertarik untuk menetap di wilayah ini. Selain para pembudidaya dan pengolah kerang hijau yang memanfaatkan wilayah ini terdapat nelayan tangkap, pengolah ikan asin, pencari kepiting, penjual besi tua yang berasal dari bongkaran kapal-kapal yang telah rusak, dll. Perairan Kalibaru pun merupakan jalur lintasan bagi kapal-kapal besar yang akan berlabuh dan berlayar dari Pelabuhan Internasional Tanjungpriok. Kondisi ini tentunya merupakan pembatas bagi para pembudidaya kerang hijau sehubungan dengan alat tangkapnya yang bersifat menetap sehingga menghalangi perahu nelayan mapun kapal-kapal besar untuk melintas.

Selain dimanfaatkan secara langsung, perairan teluk Jakarta merupakan tempat pembuangan limbah industri. Limbah yang dibuang ke perairan Teluk tidak melalui teknik pengolahan limbah yang semestinya, akibatnya kontaminasi kandungan tercemar di perairan ini semakin meningkat dan berada di atas ambang toleransi. Sementara itu, kerang merupakan hewan yang bersifat menetap dan filter feeder sehingga kondisi laut yang tercemar berdampak buruk terhadap kualitas kerang dari daerah tersebut.

Kondisi ini merupakan potensi konflik kepentingan antara pembudidaya kerang hijau dengan pemanfaat laut yang lain. Konflik muncul jika batas-batas untuk mengakses atau hak-hak dalam penggunaan sumberdaya tidak ditegakkan sementara ada tuntutan untuk menjaga keberlanjutan ekosistem atau dengan pengguna lain yang mengarah pada terjadinya konflik dan degradasi lingkungan (Grima dan Berkes, 1989).

Permasalahan ini juga muncul dipicu oleh lemahnya kerangka hukum yang mengatur pengelolaan dan pemanfaatan wilayah pesisir dan lautan. Sebagai contoh, adanya UndangUndang 23 tahun 1997 tentang pengelolaan lingkungan hidup, Peraturan Pemerintah nomor 82 tahun 2001 tentang pengelolaan kualitas air dan pengendalian pencemaran air tidak diikuti oleh penegakan konsekuensi atas pelanggaran peraturan perundangan tersebut. Akibatnya, terdapat pihak pemanfaat yang dirugikan, yang dalam konteks ini adalah pembudidaya dan pengolah kerang hijau.

Berdasarkan kondisi diatas, maka penelitian ini bertujuan menganalisis eksistensi konflik dan strategi penyelesaian konflik. Hasil penelitian diharapkan dapat menjadi bahan bagi perumusan sistem pengelolaan sumberdaya pesisir dan lautan yang lebih memperhatikan kondisi faktual di masyarakat.

\section{METODOLOGI}

Penelitian dilakukan pada bulan Februari sampai dengan Oktober 2010 di Kelurahan Kalibaru Kecamatan Cilincing Kotamadya Jakarta Utara dengan pertimbangan bahwa banyak pihak yang mempunyai kepentingan atau memanfaatkan daerah pesisir di wilayah tersebut sehingga berpotensi menimbulkan konflik. 
Penelitian ini merupakan penelitian kualitatif dengan menggunakan metode studi kasus. Penentuan metode ini merujuk pada penjelasan Babbie (2004) bahwa Social researchers often speak of case studies, which focus attention on one or few instances of some social phenomenon, such as a village, a familly, or a juvenile gang. Penelitian ini fokus terhadap fenomena yang terjadi pada komunitas pembudidaya dan pengolah kerang hijau yang berada di Kelurahan Kalibaru Kecamatan Cilincing Kotamadya Jakarta Utara.

Jenis data yang dikumpulkan adalah data primer dan data sekunder yang dikumpulkan melalui teknik wawancara, observasi, dan studi literatur. Data primer menyangkut jenis konflik, persepsi masyarakat terhadap konflik, aturan pengelolaan sumberdaya berupa kesepakatan lokal. Sedangkan studi literatur dimaksudkan untuk mencari data mengenai perkembangan usaha budidaya dan pengolahan kerang hijau serta teorisasi konflik.

Wawancara dilakukan terhadap informan kunci yang selanjutnya dari informan kunci dapat diketahui para informan lain dan para responden yang lebih bisa menjelaskan permasalahan yang sedang diteliti. Informan kunci tersebut adalah petugas kelurahan Kalibaru, sedangkan informan lain adalah Suku Dinas Peternakan, Perikanan dan Kelautan Jakarta Utara, Dinas Kelautan dan Perikanan Propinsi DKI Jakarta, Ketua RT, Ketua RW serta pemuka masyarakat Kalibaru. Responden yang diwawancarai berjumlah 39 orang yang terdiri dari 8 orang pembudidaya kerang, 8 orang pengolah kerang, 7 orang merangkap sebagai pembudidaya dan pengolah, 8 orang nelayan tradisional, 3 orang nelayan bagan apung dan 1 orang pengumpul kerang dan 4 orang masyarakat sekitar yang tidak bermata pencaharian dari sumberdaya laut dan pesisir.

Analisis data dilakukan berdasarkan kerangka analisis yang dikemukakan Lewis A Coser (Poloma, 1979) yang menyatukan kedua pendekatan yaitu teori struktural fungsional dan teori konflik. Menurutnya, beberapa susunan struktural merupakan hasil persetujuan dari konsensus, suatu proses yang ditonjolkan oleh kaum fungsional struktural, tetapi Coser juga menunjukkan pada proses lain yaitu konflik sosial. Jadi dalam hal ini Coser mencoba menerapkan pendekatan struktural fungsional untuk melihat bagaimana struktural pelaku konflik tersebut terbentuk serta untuk melihat dampak dari konflik, sementara untuk melihat sumber dan proses konflik lebih banyak didekati dengan teori konflik neo marxis. Teori konflik neomarxis lebih memandang bahwa konflik tidak semata-mata karena perbedaan kelas berdasarkan penguasaan kapital, namun juga lebih memusatkan pada unsur psikologis, dimana perbedaan idea yang dimiliki seseorang lebih berperan dari pada kondisi fisiknya.

\section{HASIL DAN PEMBAHASAN}

\section{Eksistensi Konflik: Sumber, Jenis dan Aktor Yang Terlibat Dalam Konflik}

Konflik yang paling menonjol di wilayah pesisir Kalibaru adalah konflik perebutan "ruang", baik "ruang" dalam pengertian sesungguhnya yaitu wilayah pesisir dimana komunitas pembudidaya dan pengolah kerang bersama komunitas lain melakukan aktivitas ekonominya maupun "ruang" dalam pengertian abstrak yaitu ruang bagi seseorang dalam wilayah yang tidak nyata, misalnya dalam proses pembuatan rencana pengelolaan wilayah tersebut. Dominansi, kewenangan, idea-idea, berada pada wilayah ruang abstrak. Lefebvre dalam Ritzer dan Goodman (2008) seorang tokoh neo marxis mengistilahkan ruang sesungguhnya itu sebagai ruang absolut, sementara ruang yang lebih abstrak dinamakan ruang abstrak. Menurutnya, ruang abstrak merupakan alat untuk memperoleh kekuasaan atas ruang absolut.

Berdasarkan hal tersebut, maka konflik yang terjadi pada ruang abstrak di pesisir Kalibaru menyangkut konflik pemaknaan dan konflik kewenangan, sementara konflik yang terjadi pada ruang absolut yaitu konflik perebutan wilayah pesisir dan konflik lingkungan hidup. Keempat konflik ini saling berhubungan dan menjadi salah satu faktor penyebab munculnya konflik yang lain. 
Gambar 1 menunjukkan hubungan antara ke empat jenis konflik yang terjadi di pesisir Kalibaru berkaitan dengan aktivitas pembudidayaan dan pengolahan kerang hijau.

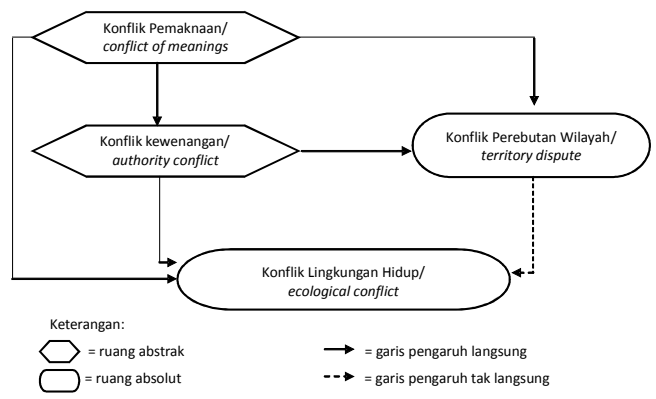

\section{Gambar 1. Hubungan Antar Konflik di Wilayah Pesisir Kalibaru.}

Figure 1. Relationships With Conflicts in Coastal Areas Kalibaru.

Gambar di atas menunjukkan hubungan antara ke empat jenis konflik yang saling mempengaruhi. Konflik yang satu bukan menjadi penyebab tunggal terjadinya konflik yang lain, namun hanya sebagai salah satu faktor pendorong munculnya konflik yang lain. Konflik perebutan wilayah pesisir antara nelayan dan pembudidaya misalnya, tidak hanya disebabkan karena tidak terselesaikannya konflik kewenangan atau ketidaktahuan nelayan terhadap aturan yang ada namun juga terdapat faktor yang lain yaitu semakin sempitnya jalur pelayaran akibat adanya bagan yang tidak sesuai aturan.

Konflik pemaknaan menjadi salah satu faktor penyebab dari setiap konflik yang terjadi, karena pada dasarnya orang mempunyai alasan atau pembenaran tersendiri terhadap setiap tindakan yang mereka lakukan. Perbedaan pemaknaan ini cenderung dapat mudah untuk disamakan atau diselesaikan bila yang berkonflik mempunyai posisi yang sama, namun akan sulit diselesaikan bila pihak yang berkonflik berada pada status yang berbeda atau merasa pada posisi yang lebih tinggi dibandingkan pihak lawan. Konflik antara perintah dengan komunitas pembudidaya dan pengolah kerang akan lebih sulit diselesaikan dibandingkan dengan konflik yang terjadi antara pembudidaya kerang dengan nelayan.

Pembahasan mengenai jenis konflik dan pelaku-pelaku yang terlibat didalamnya dibagi menjadi tiga bagian yaitu konflik kewenangan, konflik perebutan wilayah dan konflik lingkungan hidup, sedangkan konflik pemaknaan akan dibahas dalam ketiga jenis konflik tersebut.
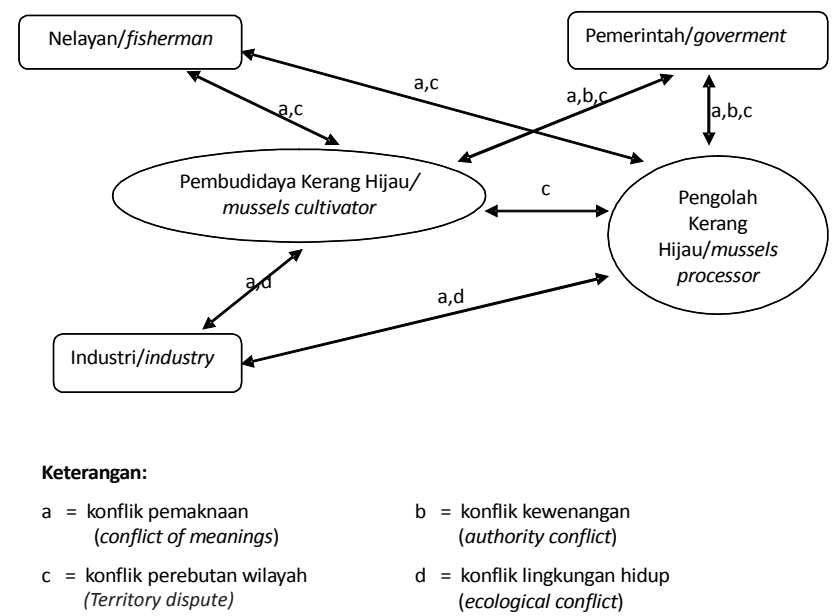

$\mathrm{b}=$ konflik kewenangan (authority conflict)

$\mathrm{d}=$ konflik lingkungan hidup (ecological conflict)

Gambar 2. Konflik dan Potensi Konflik Antara Pembudidaya dan Pengolah Kerang Hijau dengan Pelaku Lain.

Figure 2. Conflict and Potential Conflict Between Cultivator And Processor of Green Mussels (Perna Viridis) With Other Agents. 


\section{a. Konflik kewenangan}

Konflik kewenangan terhadap pengelolaan wilayah pesisir Kalibaru terjadi antara pemerintah dan komunitas pembudidaya dan pengolah kerang hijau. Kewenangan yang dimaksud meliputi kewenangan dalam mengelola dan memanfaatkan sumberdaya laut dan pesisir. Konflik ini disebabkan oleh tidak selarasnya aturan formal dengan kesepakatan lokal yang dibuat oleh masyarakat. Konflik ini berawal dari perbedaan pemaknaan terhadap pemilikan wilayah pesisir. Dalam kasus di Kalibaru, dapat dikatakan bahwa konflik kewenangan merupakan wujud kongkrit dari konflik pemaknaan yang bersifat abstrak.

Pemaknaan tersebut erat kaitannya dengan pengetahuan yang dimiliki oleh masingmasing pihak yang berkonflik. Masyarakat memaknai laut dan wilayah sebagai wilayah pemberian Tuhan untuk semua umatNya, sehingga wilayah ini merupakan milik bersama yang dapat dimanfaatkan bersama sesuai dengan kesepakatan-kesepakatan yang telah mereka buat bersama. Kesepakatan tersebut telah menjadi aturan yang ditaati oleh masyarakat secara turun-temurun. Wilayah selama ini mereka tempati merupakan warisan dari nenek moyang yang lebih dulu menempati wilayah tersebut sebelum peraturan-peraturan pemerintah dibuat.

Sementara pemerintah sebagai pemegang kewenangan secara yuridis formal untuk mengatur pengelolaan sumberdaya, memaknai laut dan pesisir sebagai wilayah dimana pengelolaannya menjadi otoritasnya dan masyarakat sebagai warga negara yang baik harus patuh pada semua kebijakan yang diambil oleh pemerintah. Melihat kondisi wilayah pesisir Kalibaru sekarang ini, khususnya untuk wilayah yang didominasi oleh kerang hijau terlihat sangat memprihatinkan terutama dari segi tata ruang dan sanitasi, menjadi sebuah kewajaran munculnya sebuah pemikiran bahwa sistem pengelolan yang selama ini dilakukan oleh masyarakat tidak mampu menciptakan kondisi yang diharapkan sehingga pemerintah harus mengambil alih kewenangan atas pengelolaan wilayah tersebut. Konflik terjadi bila aktualisasi pemaknaan yang dimiliki pemerintah tidak selaras dengan kesepakatan-kesepakatan yang ada pada tingkat masyarakat.

Meskipun pada kondisi sekarang masyarakat Kalibaru masih hidup dalam ruang pemaknaan mereka, namun pemerintah daerah melalui peraturan-peraturan daerahnya secara perlahan mencoba menancapkan dominansinya. Pemerintah berupaya untuk menyamakan 'makna' yang dimiliki oleh masyarakat tersebut dengan memberikan pengetahuan-pengetahuan yang bertemakan "penyadaran" kepada masyarakat lokal. Upaya penyadaran ini lebih digiring kepada pemaknaan pesisir menurut pemerintah. Foucault (2002) menguraikan bagaimana pengetahuan membentuk kekuasaan atas wilayah geografis. Menurutnya, pengetahuan berfungsi sebagai sebuah bentuk kekuasaan dan sekaligus menyebarkan efek-efek kekuasaan tersebut. Pengetahuan bisa berwujud dalam penggunaan bahasa. Pembentukan UU pengelolaan pesisir yang banyak memuat kata "peran serta masyarakat" seolah memberi kesan bahwa konsesus pengelolaan wilayah dibuat secara bersama antara pemerintah dan masyarakat padahal jika dicermati lebih dalam maka makna "peran serta" tersebut sangat terbatas.

Kasus ini menunjukkan kebenaran dari analisis Foucault bahwa ada problematika dalam bentuk modern pengetahuan, rasionalitas, institusi sosial, dan subyektivitas. Semua itu, menurutnya terkesan given and natural, tetapi dalam faktanya semua itu adalah "serombongan konstruk sosiokultural tentang kekuasaan dan dominasi" yang pada akhirnya pengetahuan telah dimanipulasi untuk melanggengkan dominasi terhadap kaum marjinal.

\section{b. Konflik perebutan wilayah pesisir}

Konflik pemaknaan tidak hanya menjadi pemicu terjadinya konflik kewenangan antara masyarakat pesisir dengan pemerintah, namun juga menjadi pemicu konflik antar pengguna pesisir yang berujung pada konflik perebutan wilayah yaitu antara pembudidaya kerang dengan nelayan atau antara nelayan dengan 
pengolah kerang. Namun demikian konflik perebutan wilayah ini relatif lebih mudah diselesaikan karena sebagian besar telah tertuang dalam kesepakatan-kesepakatan bersama yang telah berlaku secara turun temurun.

Konflik antara pembudidaya kerang hijau dengan nelayan terjadi hanya seputar kerusakan bagan kerang akibat tertabrak oleh perahu nelayan. Namun hal ini bisa diselesaikan dengan baik secara kekeluargaan dengan konsekuensi nelayan harus mengganti kerusakan tersebut. Kesadaran nelayan tersebut didasari oleh pengetahuan lokal masyarakat setempat bahwa laut merupakan wilayah "milik bersama" sehingga orang bebas memanfaatkannya dengan prinsip saling menghargai usaha masing-masing, serta masih luasnya wilayah laut yang bisa dilewati tanpa harus melalui wilayah dimana bagan ditancapkan. Pencapaian kesepakatan akan lebih alot bila nelayan yang menabrak bagan adalah nelayan andon karena menurut nelayan ini laut adalah wilayah bebas sehingga kesalahan bukan karena perahu tapi karena bagan yang tidak beraturan. Namun posisi mereka yang hanya pendatang menyebabkan mereka tidak mempunyai posisi untuk melawan aturan setempat. Biasanya ganti rugi disepakati dengan mempertimbangkan kemampuan nelayan juga. Intensitas konflik cenderung akan semakin meningkat di masa yang akan datang jika jumlah bagan semakin banyak dan mendominasi wilayah perairan pesisir, sehingga tidak ada ruang bagi perahu untuk melalui wilayah ini. Dengan demikian, masyarakat harus segera membuat kesepakatan baru.

Potensi konflik perebutan wilayah pun terjadi antara pengolah kerang dan nelayan. Konflik ini berkaitan dengan penguasaan wilayah daratan oleh pengolah kerang hijau dan melekatnya hak pada pemilik daratan tersebut untuk mereklamasi wilayah laut. Kondisi ini membuat akses nelayan terhadap pesisir dan laut menjadi terbatas.

\section{c. Konflik Lingkungan Hidup}

Konflik-konflik yang terus dibiarkan tanpa penyelesaian memicu munculnya permasalahan lain yaitu konflik lingkungan hidup. Tarik menarik kepentingan antara pembudidaya dan nelayan yang membutuhkan perairan laut yang bebas pencemaran dengan pihak industri yang membutuhkan laut sebagai sarana penetralisir limbah namun tanpa melalui mekanisme pengolahan limbah yang dianjurkan telah menimbulkan permasalahan lingkungan yang akut di perairan teluk Jakarta.

Konflik bermula karena masyarakat pembudidaya kerang hijau merasa bahwa limbah pembuangan pabrik telah mencemari perairan sehingga produktivitas kerang mereka menurun drastis. Pada Tahun 2005, bentuk kekesalan warga dilakukan melalui demonstrasi ke kantor Walikota dengan tuntutan ganti rugi dan penertiban limbah. Menurut beberapa pembudidaya, sebagian pembudidaya telah menerima ganti rugi sebesar satu juta rupiah, namun pemberian ganti rugi ini telah dihentikan padahal belum semua pembudidaya mendapatkannya.

Ketika diajukan pertanyaan, bagaimana jika suatu hari tidak bisa berbudidaya kerang lagi karena laut sudah demikian tercemar? Para pembudidaya dan pengolah kerang hijau berpendapat serupa yaitu menuntut pertanggungjawaban pihak industri dan pemerintah. Jika hal ini terus berlangsung, tidak menutup kemungkinan demonstrasi serupa pada tahun 2005 atau aksi kolektif yang lain akan kembali berlangsung.

Menurunnya jumlah kerang hijau akibat pencemaran tersebut berdampak pada menurunnya produktivitas pengolah, pemasar, dan para buruh yang terlibat dalam usaha kerang pasca panen. Padahal, usaha pasca panen ini melibatkan ribuan orang yang hidupnya sangat tergantung pada usaha ini.

Sulit mengurai pihak industri mana yang terlibat dalam pencemaran teluk Jakarta, karena selain pabrik-pabrik besar yang terdapat di sekitar teluk Jakarta, Teluk Jakarta pun merupakan muara dari 13 Sungai yang tidak 
menutup kemungkinan industri-industri yang terdapat di kawasan sekitar daerah aliran sungai pun memanfaatkan aliran sungai tersebut untuk membuang limbangnya tanpa melalui pengolahan limbah terlebih dahulu. Kondisi ini diperparah dengan tidak ditegakkannya pengawasan terhadap mekanisme pengelolaan limbah kepada semua pihak industri baik yang berskala besar maupun yang berskala rumahan. Timbulnya masalah lingkungan dikarenakan tidak adanya kebijakan politik yang secara tegas dan jelas menempatkan kedudukan strategis sumberdaya kelautan dan pesisir sebagai entitas pembangunan nasional (Kusnadi, 2006).

\section{Strategi Penyelesaian Konflik}

Beberapa konflik cenderung mempunyai fungsi bila dapat diselesaikan dengan baik berdasarkan mekanisme penyelesaian konflik yang tertuang dalam kesepakatan lokal yang telah menjadi aturan bersama dalam masyarakat. Sementara konfik menjadi disfungsional ketika penyelesaian konflik tidak diatur dalam kesepakatan bersama, sehingga sulit membuat konsensus antara pihak-pihak yang berkonflik. Konflik yang bersifat disfungsional di Kalibaru terjadi antara komunitas pembudidaya kerang hijau yang memerlukan wilayah perairan pesisir yang bebas pencemaran dengan pihak industri yang menggunakan perairan pesisir sebagai sarana untuk membuang limbahnya. Perebutan wilayah ini menimbulkan konflik baru yaitu konflik lingkungan hidup.

Konflik yang terjadi antar pelaku yang mempunyai kepentingan terhadap pesisir Kalibaru diselesaikan dengan cara yang berbeda-beda berdasarkan pelaku yang berkonflik dan permasalahan yang terjadi.

\section{a. Penyelesaian Konflik Kewenangan}

Konflik ini berkaitan erat dengan pelaksanaan kesepakatan lokal yang tidak selaras dengan peraturan formal. Bertahannya aktivitas pembudidayaan dan pengolahan kerang hijau di wilayah Kalibaru bukan karena telah terjalinnya keselarasan antara kesepakatan lokal dan kebijakan formal, namun pemerintah sementara ini membiarkan masyarakat hidup dalam tata aturan kesepakatan lokal untuk menghindari potensi konflik yang akan terjadi jika aturan formal diterapkan.

Mencermati dasar kebijakan yang dilakukan pemerintah dalam penyelesaian konflik seperti ini, maka dapat dikatakan bahwa pemerintah sedang menyelesaikan konflik dengan cara menarik konflik ke dalam perundang-undangan yang dibuat kemudian oleh pemerintah. Berdasarkan perundangundangan yang ada, pembudidaya dan pengolah kerang hijau sudah tidak dapat melakukan aktivitas usaha kerangnya karena kerang di perairan tersebut sudah tercemar. Oleh karenanya, pemerintah merencanakan adanya relokasi bagi masyarakat ke daerah dimana perairannya masih baik atau melakukan alih mata pencaharian. Namun demikian, pemerintah belum sepenuhnya melaksanakan aturan tersebut karena belum adanya konsep yang jelas mengenai program reposisi aktivitas ekonomi masyarakat setempat yang mampu menjamin keberlangsungan kehidupan sosial dan ekonominya.

\section{b. Penyelesaian konflik perebutan wilayah}

Penyelesaian konflik antar pelaku baik antara pembudidaya dan pengolah kerang hijau dengan pelaku lain yang memanfaatkan sumberdaya secara langsung (nelayan) dilakukan secara kekeluargaan. Contoh kasus rusaknya bagan karena tertabrak perahu nelayan cukup diselesaikan dengan cara pihak nelayan membayar sejumlah uang ganti rugi kerusakan kepada pemilik bagan.

Hubungan antara komunitas pembudidaya kerang dan pengolah kerang dengan komunitas nelayan terlihat lebih harmonis setelah adanya HKBNPK (Himpunan Keluarga Besar Nelayan Pesisir Kalibaru). Anggota HKBNPK berasal dari berbagai profesi di bidang hasil laut yaitu nelayan bagan tancap, nelayan bagan apung, peternak kerang ataupun pengolah kerang. Organisasi ini didirikan atas 
dasar rasa saling berbagi antar anggota, dan untuk anggota yang bersangkutan bisa dijadikan semacam asuransi. Ketika ada anggota yang terkena musibah misalnya sakit maka HKBNPK akan memberikan sejumlah uang bagi biaya pengobatan. Begitu pun pada waktu musim paceklik tiba maka HKBNPK akan memberikan sejumlah bantuan yang besarnya disepakati bersama. Masing-masing anggota membayar iuran sejumlah Rp. 10.000/orang pada setiap bulannya.

Organisasi ini pun sering menyalurkan bantuan-bantuan dari pihak-pihak yang berempati terhadap warga pesisir Kalibaru ketika musim Paceklik tiba. HKBNPK ini diharapkan mampu ikut bagian dalam menciptakan kerukunan hidup baik antara peduduk yang memiliki berbagai profesi maupun sebagai perekat kepedulian antar berbagai kelas yang terdapat di wilayah Kalibaru ini, sehingga harmonisasi dapat diwujudkan dan posisi masyarakat lokal dalam berbagai kebijakan khususnya dalam pengelolaan sumberdaya pesisir dapat diperhitungkan.

\section{c. Penyelesaian konflik lingkungan hidup}

Konflik yang terjadi antara pembudidaya dan pengolah kerang hijau dengan pihak industri merupakan potensi konflik yang akan berulang bila aturan formal yang ada tidak ditegakkan sebagaimana mestinya. Potensi konflik ini berkaitan erat dengan pengaruh limbah industri terhadap produktivitas kerang hijau. Potensi konflik tersebut akan menjadi konflik yang tajam bila kerang yang mati mencapai 100 persen. Kasus yang terjadi pada tahun 2005 ketika kerang hijau di perairan teluk Jakarta mati semua, para pembudidaya melakukan aksi demonstrasi kepada industriindustri yang berada di kawasan tersebut melalui Walikota. Namun cara tersebut sudah dianggap tidak efektif karena tidak semua pembudidaya yang mengalami kerugian mendapatkan ganti rugi.

Seringnya konflik yang terjadi antara pembudidaya dan pengolah kerang hijau dengan pihak industri menumbuhkan kesadaran diantara pembudidaya dan pengolah kerang hijau untuk membentuk kelompok tersendiri yang beranggotakan pembudidaya dan pengolah kerang hijau. Pada saat penelitian ini dilaksanakan, upaya kearah pembentukan kelompok sudah sampai kepada rekapitulasi calon anggota. Melalui kelompok ini para pembudidaya dan pengolah kerang hijau berharap mempunyai kekuatan ketika ada permasalahan.

Ecological conflict ini merupakan permasalahan yang sulit diselesaikan karena tidak hanya menyangkut pelaku disekitar kawasan pesisir namun juga menyangkut pelaku-pelaku di daerah-daerah sepanjang aliran sungai yang bermuara ke Teluk Jakarta. Oleh karena itu penyelesaiannya membutuhkan koordinasi lintas departemen dan lintas sektoral yang tentunya membutuhkan waktu yang tidak sebentar.

\section{KESIMPULAN DAN IMPLIKASI KEBIJAKAN}

Sumber konflik dalam aktivitas pembudidayaan dan pengolahan kerang hijau di Kalibaru berawal dari perbedaan pemaknaan antar pihak yang berkonflik, serta penegakkan aturan yang belum semestinya. Kondisi ini didorong oleh belum adanya konsep yang jelas untuk mengantisipasi dampak dari penegakan aturan yang dibuat. Jenis konflik terdiri dari konflik kewenangan, konflik perebutan wilayah dan konflik ekologi. Konflik ini mengakibatkan terjadinya ketegangan antara pelaku dan mengakibatkan komunitas pembudidaya dan pengolah kerang hijau berada pada ketidakpastian atas hidup dan penghidupannya. Namun demikian konflik ini pun mempunyai dampak positif yaitu menumbuhkan kesadaran pada pembudidaya dan pengolah kerang hijau untuk berkelompok, mempercepat terjadinya penyelesaian atas isu-isu yang berkembang selama ini, serta membimbing kepada aliansi antar kelompok yang berkepentingan.

Konsep yang digagas Satria (2009) sepertinya dapat dilakukan oleh Pemerintah daerah DKI Jakarta untuk mengelola konflik dan menekan potensi konflik yang terjadi di wilayah teluk Jakarta. Satria menawarkan beberapa agenda pada aras mikro untuk mengantisipasi 
konflik nelayan yaitu pengukuhan model sumberdaya berbasis masyarakat, penguatan organisasi nelayan, kerjasama lintas daerah, dan pemberdayaan nelayan. Berdasarkan hal tersebut, maka perlu dibentuk organisasi pembudidaya dan pengolah kerang hijau, serta perlu dibuat model reposisi aktivitas pembudidaya dan pengolah kerang hijau berdasarkan aspirasi dan kondisi sosial, budaya dan ekonomi masyarakat. Sementara pada aras makro, pengelolaan sumberdaya laut memerlukan kerangka hukum yang jelas dengan implementasi yang tegas dengan berdasarkan keberpihakan utuh terhadap kepentingan masyarakat. Salah satu contoh adalah Peraturan Pemerintah No. 82 tahun 2001 tentang pengelolaan kualitas air dan pengendalian pencemaran air harus ditegakkan dengan menerapkan sanksi terhadap setiap pelanggaran atas aturan tersebut.

\section{DAFTAR PUSTAKA}

Anonim. 1997. Undang-Undang Republik Indonesia Nomor 23 Tahun 1997 Tentang Pengelolaan Lingkungan Hidup. . 2001. Peraturan Pemerintah Republik Indonesia No 82 Tahun 2001 tentang pengelolaan kualitas air dan pengendalian pencemaran air.
Kerang Hijau di Teluk Jakarta. Dinas Peternakan, Perikanan dan Kelautan DKI Jakarta. Jakarta.

Babbie, E. 2004. The Practice of Social Research. Thomson Wadsworth. USA.

Baedhowi. 2001. Studi Kasus dalam Teori dan Paradigma Penelitian Sosial oleh Salim, Agus (ed.). PT. Tiara Wacana. Yogyakarta. . 2010. Kajian Eksistensi Budidaya Foucault, M. 2002. Power/Knowledge: Wawancara Pilihan dan Tulisan-tulisan Lain 1972-1977. Bentang Budaya. Yogyakarta.

Grima dan Berkes, F. 1989. Common Property Resources: Ecology and community-based Sustainable development. Belhaven Press. London.

Kusnadi. 2006. Konflik Sosial Nelayan: Kemiskinan dan Perebutan Sumber Daya Alam. LKiS Yogyakarta.

Poloma, M. M. 1979. Sosiologi Kontemporer. PT. RajaGrafindo Persada. Jakarta.

Ritzer, G. dan D. J. Goodman, 2008. Teori Sosiologi: Dari Teori Sosiologi Klasik sampai Perkembangan Mutakhir Teori Sosial Postmodern. Kreasi Wacana. Yogyakarta.

Satria, A. 2009. Ekologi Politik Nelayan. LKIS. Yogyakarta. 